Jurnal Ilmu Administrasi Publik 7 (2) (2019): 71-87

DOI: http://dx.doi.org/10.31289/publika.v7i2.2805

Jurnal Administrasi Publik

http://ojs.uma.ac.id/index.php/publikauma

\title{
Kajian Wilayah Birokrasi Bersih dan Melayani Kepolisian Resort Kota Besar Medan
}

\author{
Dadang Hartanto* \\ *Program Studi Administrasi Publik, Universitas Muhammadiyah \\ Sumatera Utara, Indonesia
}

Diterima Agustus 2019; Disetujui Oktober 2019; Dipublikasikan Desember 2019

\begin{abstract}
Abstrak
Reformasi Birokrasi Pemerintah Indonesia dimulai sejak terterbitnya Peraturan Presiden Nomor 80 Tahun 2011 tentang Grand Desain Reformasi Birokrasi Indonesia 2010-2025 dan Peraturan Menteri Pendayagunaan Aparatur Negara dan Reformasi Birokrasi Nomor 20 Tahun 2010 tentang Road Map Reformasi Birokrasi 2010-2014. Melalui kedua pedoman tersebut Polrestabes Medan mulai menerapkan secara bertahap reformasi birokrasi. Tujuan penelitian ini adalah untuk mengetahui proses pencapaian wilayah birokrasi bersih dan melayani Polrestabes Medan. Metode penelitian yang digunakan adalah deskriptif kualitatif dengan didukung data sekunder. Hasil penelitian ini menunjukkan bahwa dalam perjalanannya penerapan dan pelaksanaan reformasi birokrasi terdapat area perubahan dan program yang membuahkan beberapa capaian dan perkembangan yang baik. Aspek pencapian tersebut tidak terlepas dari indikator yang telah ditetapkan yaitu perubahan mind set,pembenahan sistem pelayanan publik berbasis IPTEK, Penguatan Peraturan dan Kepemimpinan.
\end{abstract}

Kata kunci : Birokrasi, Perubahan, Kepolisian, Wilayah, Melayani

The Indonesian Government's Bureaucratic Reform began since the Presidential Regulation Number 80 Year 2011 regarding the Grand Design of the Indonesian Bureaucratic Reform 2010-2025 and the Minister of Administrative Reforms and Bureaucracy Reform Number 20 of 2010 concerning the Road Map of the 2010-2014 Bureaucracy Reform. Through these two guidelines Medan Polrestabes began to gradually implement bureaucratic reform. The purpose of this study was to determine the process of achieving a clean bureaucratic area and serving Medan Polrestabes. The research method used is descriptive qualitative supported by secondary data. The results of this study indicate that in the course of implementing and implementing bureaucratic reforms there are areas of change and programs that produce some good achievements and developments. The aspect of ignition is inseparable from the indicators that have been set, namely the change of mind set, revamping the public service system based on science and technology, Strengthening Regulations and Leadership

Keywords : Bureaucracy, Reform, Region, Services

How to Cite : Hartanto ,D. (2019). Kajian Wilayah Birokrasi Bersih dan Melayani Kepolisian Resort Kota Besar Medan, 7 (2) : 71-87

*Corresponding author: P-ISSN-2549-9165

E-mail: dadanghartanto@umsu.ac.id e-ISSN -2580-2011 


\section{PENDAHULUAN}

Dalam kurun waktu sepuluh tahun terakhir, berbagai penilaian terbaru diperoleh kepolisian dari berbagai kalangan masyarakat. Sejauh ini perubahan struktural dan instrumental relatif berlangsung dengan baik, tetapi perubahan kultural masih menjadi persoalan yang belu terpecahkan. Demikian pula perubahan dalam kelembagaan dan budaya Polri yang belum menyentuh akar "konservatisme" budaya yang sulit untuk berubah (Karnavian, 2017).

Pelaksanaan tugas Polri pada Renstra 2015-2019 diarahkan untuk mencapai tujuan dalam rangka mewukudkan organisasi Polri menuju National Class Organization (NCO) hingga mencapai status Word Class Organization (WCO) pada tahun 2025; organisasi Polri dengan Good and Clean Governance, perubahan mind set dan culture set menuju Pemolisian Demokratis (Democratic Policing); rasa aman dan nyaman dimasyarakat dalam melaksanakan aktivitas dan kegiatan dankehidupan sehari- hari.

Polri yang profesional dan berkompeten, bermoral, modern, unggul serta terpercaya masyarakat; dan penegak hukum yang transparan, akuntabel dan anti KKN mampu memberikan perlindungan dan pengayoman masyarakat serta memenuhi rasa keadilan masyarakat, yang tak lain sebagai aktualisasi arah kebijakan pemerintah dalam Nawa Cita menuju perubahan dengan menghadirkan negara yang bekerja, kemandirian yang mensejahterahkan, dan revolusi mental sebagai mana tertuang dalam RP JMN Tahun 2015-2019.

Untuk mencapai tujuan tersebut diperlukan kerjasama organisasi birokrasi. Birokrasi merupakan suatu prosedur yang dilaksanakan sesuai dengan ketentuan yang berlaku dan dijalankan oleh keseluruhan aparat pemerintah guna mencapai tujuan organisasi dengan maksud mengorganisir secara teratur suatu pekerjaan yang harus dilakukan oleh banyak orang. Birokrasi melaksanakan kegiatan-kegiatan regular yang dibutuhkan untuk mencapai tujuantujuan orgnaisasi, didistribusikan melalui cara-cara tertentu dan dianggap sebagai tugas-tugas resmi.

Pembagian tugas secara tegas memungkinkan untuk mempekerjakan hanya ahli-ahli spesialisi tertentu pada jabatan-jabatan tertentu dan membuat 
mereka bertanggungjawab atas pelaksanaan tugas masing-masing secara efektif. Tingkat spesialisasi yang tinggi ini menjadi bagian dari kehidupan sosial ekonomi sehingga kita cenderung lupa bahwa hal ini merupakan inovasi birokratis yang relatif baru dan belum pernah ditemui pada masa-masa lalu.

Birokrasi juga dapat digunakan sebagai alat pembaruan. Ini akan terlaksana jika tujuan-tujuan organisasi memang diarahkan kepada strategi pembaruan dan pembangunan. Untuk dapat merealisasi cita-cita pembangunan sosial-ekonomi, pemerintah harus memiliki pranata-pranata yang mudah menerima inovasi-inovasi baru yang bermanfaat bagi pembangunan. Tak pelak lagi, birokrasi merupakan alat penunjang utama didalam sistem administrasi modern. Dasar dari legitimasi dalam struktur pemerintah adalah penerapan pengetahuan, rasionalitas dan teknologi. Lepas dari itu birokrasi menjadi satusatunya perangkat yang lebih peka terhadap teknologi. Bila kita menolak birokrasi dan hendak menggantinya dengan sistem yang lain, itu berarti langkah mundur yang sudah pasti akan merugikan (Kumorotomo, 2015).
Dalam perjalanannya, terdapat kendala yang dihadapi, seperti adanya penyalagunaan wewenang, pratek KKN, diskriminasi dan lemahnya pengawasan. Ada beberapa hal yang dapat dikemukakan untuk menjelaskan mengapa selama ini banyak kebijakan, program dan pelayanan publik kurang responsif terhadap aspirasi masyarakat sehingga kurang mendapat dukungan secara luas. Pertama, para birokrat kebanyakan masih berorientasi kepada kekuasaan dan bukannya kepentingan publik atau pelayanan publik secara umum.

Sebagian besar pejabat atau birokrat itu selama ini menempatkan dirinya dalam posisi sebagai penguasa (authorities) dan masih sangat terbatas pejabat yang menyadari peranannya sebagia penyedia layanan kepada masyarakat (public servant/service provider). Budaya paternalistic seringkali juga mengakibatkan turunnya kualitas pelayanan publik. Budaya semacam ini mengakibatkan kecenderungan untuk memberikan keistimewaaan kepada para elit birokrat atau orang-orang yang memiliki hubungan dekat dengan mereka.

Kedua, terdapat kesenjangan yang lebar antara apa yang diputuskan oleh 
pembuat kebijakan dan apa yang benarbenar dikehendaki oleh rakyat. Sistem administrasi publik dan mekanisme politik yang berlaku ternyata gagal menjembatani kepentingan elit politik dan rakyat pada umumnya. Namun tanpa kontrol dan sistem akuntabilitas yang cukup kuat, senantiasa terdapat kemungkinan bahwa aparat birokrasi akan merumuskan dan melaksanakan kebijakan, melaksanakan aktivitas pelayanan publik hanya berdasarkan kepentingan sempit (vested interests) dari elit atau para penguasa (Kumorotomo, 2015).

Kepentingan sempit dilakukan antara lain dalam bentuk perilaku koruptif. Salah satu langkah riil yang saat ini dilakukan untuk menghilangkan perilaku penyimpang dan koruptif anggota polri adalah pembangunan Wilayah Bebas Korupsi (WBK) dan Wilayah Bersih Birokrasi dan Melayani (WBBM). Hal tersebut dilaksanakan dengan membangun Zona Integritas yang difokuskan pada penerapan program Menajemen Perubahan, Penataan Tata Laksana, Penataaan Manajemen SDM, Penguatan Pengawasan, Penguatan Akuntabilitas Kinerja, dan Peningkatan
Kualitas Pelayanan Publik yang bersifat kongkrit.

Dalam upaya mewujudkan Zona Integritas menuju Wilayah Bebas Birokrasi Bersih dan Melayani (WBBM) di lingkungan Polrestabes Medan harus mengacu kepada Peraturan Menteri Pendayagunaan Aparatur Negara dan Reformasi Birokrasi Nomor 22 Tahun 2014 tentang Pedoman Pembangunan Zona Integritas menuju Birokrasi Bersih dan Melayani (WBBM) di lingkungan instansi pemerintah serta Keputusan Kepala Kepolisian Negara Republik Indonesia Nomor : Kep / 580 / VI / 2016 tanggal 9 Juni 2016 tentang Petunjuk Pembangunan Zona Integritas menuju Wilayah Bebas dari Korupsi (WBK) dan Birokrasi Bersih dan Melayani (WBBM) di Lingkungan Polri.

Berangkat dari dasar hukum dan program diatas dianggap penting menyajikan dan menganalisis target dan capaian serta inovasi yang telah dilaksanakan selama ini guna memberikan sebuah gambaran keberadaan Polrestabes Medan dalam memberikan pelayanan kepada masyarakat.

\section{METODE PENELITIAN}

Jenis penelitian ini adalah penelitian kualitatif. Teknik pengumpulan data 
menggunakan observasi, wawancara, dan dokumentasi. Untuk menguatkan hasil penelitian ini ditambah dengan dukungan data-data serta literatur dari berbagai laporan kegiatan Polretabes Medan dan hasil survey kepuasan masyarakat terhadap pelayanan Polrestabes Medan. Tehnik analisis data menggunakan analisis deskriptif kualitatif.

\section{HASIL DAN PEMBAHASAN}

\section{Perubahan Mindset}

Banyak pendapat bahwa untuk dapat bertahan dalam situasi diperlukan kemampuan adaptasi yang baik sehingga mampu menyesuaikan dengan apapun perubahan yang terjadi. Bentuk adaptasi yang dapat dilakukan salah satunya adalah melakukan inovasi dalam setiap bidang yang digeluti.

Oleh karena itu penting bagi setiap organisasi kepolisian untuk memiliki Innovation mindset yaitu pola pikir yang memungkinkan terlaksananya pengembangan dan penerapan ide-ide baru. Innovation mindset melahirkan pemikiran yang inovatif, menekankan pentingnya pengembangan dan aplikasi teknologi, yang senantiasa memantau perkembangan di luar organisasi kepolisian untuk mengidentifikasi peluang, metode dan teknik terbaru untuk bisa menerapkan kualitas pelayanan yang maksimal dan memperoleh kepercayaan public.

Menurut (Lahiri, et al , 2008) atribut penting dalam innovation mindset adalah mengikuti perkembangan teknologi di dalam industri, merespon perkembangan teknologi dengan cepat, menghargai ideide dan model baru, mampu mengidentifikasi sumber-sumber ide baru di dalam maupun di luar organisasi kepolisian, melakukan pengembangan produk/jasa, mengedepankan next practice dibandingkan best practice (dalam www.sbm.itb.ac.id/id/menciptaka n-innovation-mindset). Agar efektif dalam implementasinya, menurut George (http://georgecouros.ca/archives/4783) berikut beberapa karakteristik yang perlu dimiliki innovator's mindset:

1. Emphatetic, karakteristik ini diperlukan karena untuk membangun cara baru dan lebih baik dalam melakukan sesuatu kita perlu memahami siapa yang akan menggunakannya dan untuk apa.

2. Problem finders, setiap inovasi berawal dari pertanyaan dan permasalahan bukan jawaban. Maka jika ingin menjadi inovatif kita perlu 'bertanya' terlebih 
dahulu mengenai peluang apa yang bisa dilakukan untuk perbaikan.

3. Risk-takers, berani mencoba sesuatu yang berbeda akan lebih berharga daripada hanya mencontoh best practices.

4. Networked, inovasi tidak akan terjadi dalam keterisolasian. Seringkali ide yang baru dan lebih baik muncul saat ada situasi saling berbagi ide.

5. Observant, inovasi muncul karena mengobservasi apa yang telah dilakukan oleh orang lain/organisasi lain/perusahaan lain. Hal ini sangat normal terjadi, sehingga diperlukan karakteristik pengamat yang merekam apa yang terjadi di sekeliling kita.

6. Creators, banyak orang yang memiliki ide bagus namun tidak ada tindakan dan tidak memberikan dampak nyata. Inovasi adalah kombinasi dari ide dan kerja keras. Tanpa tindakan, ide yang brilian akan lenyap begitu saja.

7. Resilient, sesuatu yang baru tidak begitu saja akan berhasil dilakukan dalam satu kali percobaan, maka perlu kemauan yang kuat dan tindakan untuk terus mencoba dan berhasil sampai pada inovasi yang diharapkan.

8. Reflective, diperlukaan jeda untuk merefleksikan kembali proses inovasi yang telah dilakukan; apa yang berhasil dilakukan, apa yang gagal, apa yang dapat dilakukan selanjutnya, dsb

Dalam mengembangkan innovation mindset diperlukan iklim organisasi yang mendukung dapat membangun innovation mindset personil dengan mengembangkan iklim yang selalu membiasakan untuk berpikir berbeda (think different), bertindak berbeda (act different) dan mencapai sukses luar biasa (achieve extraordinary success).

Berpikir berbeda (Think different) tidak semua ide layak dikejar. Langkah pertama adalah mempersempit ide yang banyak dan bertebaran ke ide yang memberikan peluang berharga.

\section{Pembenahan Sistem Pelayanan Publik Berbasis IPTEK}

Penyelenggaraan pelayanan publik merupakan upaya suatu organisasi untuk memenuhi kebutuhan dasar dan hak-hak sipil setiap warga negara yaitu pelayanan administrasi yang memiliki standar dan peraturan. Polrestabes Medan melakukan pembenahan sistem melalui cara yaitu penetapan peraturan dan SOP, penempatkan SDM sesuai kompetensinya untuk mengawasi dan mengawaki sistem serta penerapan manajemen pelayanan berbasis IT. Pertama, standar pelayanan 
publik merupakan pernyataan mengenai janji dan kewajiban unit kerja Polrestabes Medan kepada masyarakat.

Penyusunan standar pelayanan publik tersebut telah dilakukan dengan memperhatikan prinsip, standar, pola penyelenggara, biaya penyelenggara, pelayanan bagi penyandang cacat, lanjut usia, wanita hamil, dan balita, pelayanan khusus, biro jasa pelayanan, tingkat kepuasan masyarakat, pengawasan penyelenggaraan, penyelesaian pengaduan serta evaluasi kinerja pelayanan masyarakat. Prinsip pelayanan publik yang dilakukan mengacu kepada Keputusan MENPAN Nomor 63 tahun 2003 yaitu:

1) kesederhanaan, prosedur pelayanan yang tidak berbelit-belit sehingga mudah dipahami dan mudah dilaksanakan,

2) kejelasan, persyaratan teknis dan administrasi publik dan unit kerja/pejabat yang berwenang dalam penyelesaian keluhan

3) kepastian waktu

4) akurasi pelayanan, produk layanan diterima dengan benar, tepat dan sah

5) keamanan, proses pelayanan memberikan rasa aman dan kepastian hukum
6) tanggungjawab,

pimpinan bertangggungjawab dalam penyelesaian keluhan/persoalan dalam pelayanan masyarakat

7) kelengkapan sarana dan prasarana, tersedianya sarana dan prasarana dan peralatan pendukung

8) kemudahan akses, tempat lokasi dan mudah dijangkau oleh masyarakat

9) kedisiplinan, Kesopanan, Keramahan, dan bersifat ikhlas dan

10) kenyamanan lingkungan pelayanan yang tertib terratur dan disediakan ruang tunggu yang nyaman, bersih, rapi, dilengkapi dengan fasilitas pendukung seperti tempat parker, toilet, tempat ibadah.

Kedua, penempatan sumberdaya manusia sesuai kompetensinya yaitu penempatan personel dalam proses pemberian tugas dan pekerjaan yang lulus dalam seleksi untuk dilaksanakan sesuai dengan ruang lingkup yang telah ditetapkan, serta mampu mempertanggungjawabkan atas segala risiko dan kemungkinan-kemungkinan atas tugas dan pekerjaan, wewenang, dan tanggungjawab tersebut. Tidak adanya kekhususan tugas dalam Polri membuat setiap personel Polri harus selalu siap 
untuk ditempatkan dimana saja. Namun yang diharapkan adalah kesempatan untuk semua personel Polrestabes Medan dalam memperoleh penempatan yang sesuai dengan kompetensinya serta penyebarannya yang merata. Penyebaran personel yang merata di seluruh satuan Polrestabes Medan sudah sesuai, sehingga dengan penyebaran personel yang merata tersebut satuan-satuan dapat menjalankan tugasnya dengan maksimal dan secara keseluruhan kesiapan operasional semakin baik karena adanya jumlah personel yang mencukupi.

Upaya yang dilakukan dalam pemerataan dan penyebaran personil tersebut tidak terlepas dari kompetensi yang dimilikinya karena dalam hal ini Polrestabes Medan melakukan pengembangan Assesment Center untuk menjamin mutu kompetensinya sebelum dilakukan mutasi atau penempatan. Tujuannya tidak lain adalah untuk menggali level kompetensi seorang personil kepolisian melalui serangkaian jenis tes (multiple test), dan biasanya juga dilakukan oleh lebih dari satu penilai (rater).

Berdasarkan sejumlah riset empirik, assessment center diketahui memiliki validitas yang tinggi dalam memprediksi level kompetensi individu. Metode assessment center ini hanya digunakan untuk menguji jenis kompetensi soft (soft competency) atau sering juga disebut sebagai managerial competencies (contohnya: kompetensi leadership, communication skills, problem solving skills, team skills, dan sejenisnya. Hal tersebut juga dipertegas di dalam Peraturan Kepala Kepolisian Negara Republik Indonesia Nomor 16 tahun 2012 Tentang Mutasi anggota kepolisian negara republik Indonesia yaitu upaya memenuhi kebutuhan sumber daya manusia yang profesional pada setiap satuan kerja Kepolisian Negara Republik Indonesia, diperlukan sistem pembinaan karier yang terencana, prosedural, dan konsisten.

Ketiga, menajemen pelayanan berbasis IT yang ditekankan kepada kemampuan menajemen sistem personil Polrestabes dalam menciptakan dan memanfaatkan media berbasis online. Model ini membantu organisasi kepolisian untuk menyediakan pelayanan masyarakat efektif, meningkatkan efisiensi, berdayaguna tinggi serta dapat meningkatkan kerja sama/koordinasi.

Sistem informasi manajeman pelayanan masyarakat yang dibuat langsung oleh Polrestabes Medan 
merupakan bentuk proses kerja yang transparan dan efisien serta memperlancar transaksi dan layanan kepada masyarakat.Upaya ini dapat mendorong memberikan layanan yang lebih baik pada masyarakat dimana informasi dari Polrestabes dapat dicari atau diperoleh tanpa harus secara fisik datang ke kantor karena bahan-bahan informasi tersebut tersedia dalam 24 jam sehari dan tujuh hari dalam seminggu tanpa harus bergantung pada jam operasional.

Fasilitas layanan berbasis teknologi informasi dan komunikasi yang terjangkau untuk masyarakat, penyediaan informasi yang cepat untuk masyarakat, dan peningkatan kualitas ekonomi masyarakat melalui berbagai aplikasi. Jalur komunikasi pelayanan masyarakat yang dilakukan melalui portal khusus, aplikasi ataupun media sosial seperti twitter, instagram dan facebook, sedangkan berbasis portal berupa website dan layanan aplikasi seperti aplikasi polisi kita, resimen Go, SIM online, SKCK online, SP2HP online, SPKT online, Call Center, Deli 0.0, Cybertrops, ATCS dan EOffice.

\section{Penguatan Peraturan}

Salahsatu, penguatan peraturan yang dilakukan Satuan kerja Polrestabes Medan adalah dengan menerapkan kedisiplinan dan etika yang tinggi dalam setiap melaksanakan tugasnya. Pada kenyataannya dengan kedisiplinan dan etika yang tinggi membuat anggota polisi semakin dipercaya masyarakat. Hal ini sesuai dengan hasil survey yang dilakukan pada anggota polisi di Polrestabes Medan sebanyak 30 orang $(77,5 \% 0)$ bahwa dari jumlah peserta Focus Group Discussion (FGD) anggota polisi sudah mengutamakan kedisiplinan dan etika komunikasi di setiap pekerjaannya. Dalam membangun kedisiplinan dan tanggungjawab polisi harus melaksanakan tugas dengan target yang cukup berat. Hal tersebut tidak terlepas dari bimbingan dan arahan Kapolrestabes sehingga kompetensi ini mejadi tolak ukur keberhasilan polisi sebagai pelayan masyarakat.

Selain itu, itu sangat penting juga meningkatkan kompetensi sumber daya anggota kepolisian secara simultan. Sumberdaya anggota memiliki peranan yang sangat menentukan bagi kualitas kerja anggota kepolisian. Satuan kerja Polrestabes Medan mengadopsi 
pengembangan sumber daya manusia berbasis kompetensi yang telah dikembangkan di Amerika Serikat, didasarkan kenyataan bahwa untuk memprediksi tingkat keberhasilan paling baik menggunakan pendekatan kompetensi.

Pendekatan ini mempunyai prinsip bahwa manusia dan kerja dalam satu kesatuan, dan pengamatan dilakukan secara terus menerus terhadap karakteristika manusia yang berhasil yang ada di lingkungan tersebut. Langkah ini diambil karena dengan menggunakan pendekatan psikometrik tampaknya kurang begitu cocok untuk memprediksi kemampuan seorang anggota kepolisian dalam bekerja. Anggota kepolisian dengan prestasi akademik dan hasil psikotes yang baik, belum tentu memberikan kinerja yang unggul. Untuk itu masih diperlukan suatu program pengembangan SDM berbasis kompetensi. melalui penempatan, suksesi, penilaian kinerja, pendidikan dan pelatihan, serta program kompensasi.

Demikian pula pemberian motivasi, pengembangan keterampilan dan pengetahuan anggota kepolisian, serta pengembangan kompetensi merupakan syarat untuk mencapai tujuan usaha yang bersifat strategik dari suatu Lembaga Kepolisian. Dalam rangka meningkatkan citra organisasi, setiap organisasi harus memiliki dan menciptakan keunggulan bersaing organisasi agar mampu sejajar bahkan lebih unggul dari organisasi yang lain, termasuk citra Polri. Dua komponen yang diakui dan telah terbukti mampu menciptakan keunggulan kompetitif suatu organisasi adalah komitmen dan kompetensi dari anggotanya yang terlibat. Komponen ini disebut Intellelectual Capital (Ulrich, 1998).

Komitmen yang tinggi diakui mampu membangkitkan kedekatan emosional anggota terhadap organisasi, sehingga semangat juang untuk terus melakukan perbaikan telah menyatu dalam diri mereka, perilaku anggota Polri yang menjadi rumor selama ini semakin lama akan semakin berkurang, dan bahkan akan hilang sama sekali. Dengan demikian citra Polri akan semakin meningkat dan menjadi kepercayaan masyarakat, Polri adalah mitra dan pengayom masyarakat.

Tingkat komitmen yang tinggi akan menghasilkan loyalitas yang lebih tinggi, menumbuhkan kerjasama dan meningkatkan harga diri dan rasa memiliki yang lebih besar, kewibawaan, 
keterlibatan psikologik, dan merasakan suatu kesatuan yang bersifat integral dengan organisasi (Stone, 1998). Bahkan aktivitas apapun dalam kepolisian mensyaratkan komitmen yang tinggi dari anggotanya mulai dari tingkat atas sampai tingkat bawah.

Komitmen saja tanpa didukung oleh kompetensi akan berakibat fatal, hanya akan dipenuhi oleh orang orang yang setia, loyal dan taat, tetapi tidak memiliki kemampuan yang memadai, sehingga kreativitas dan inovasi di dalam organisasi kepolisian menjadi suatu yang langka. Sementara itu lembaga kepolisian dengan banyak anggota yang berbakat dan memiliki kompetensi yang tinggi, namun tanpa komitmen yang kuat, hanyalah sekumpulan orang hebat yang kemungkinan besar tidak melakukan apapun, karena tidak memiliki komitmen.

Disisi lain penguatan peraturan dilakukan dengan pembentukan budaya sipil. Kompleksnya masalah yang dihadapi Polrestabes Medan untuk menuju polisi sipil dalam masyarakat modern dan demokratis hanya mungkin dilaksanakan dengan kemampuan yang professional dengan memberikan pengetahuan konseptual dan teoritikal mengenai berbagai permasalahan pelayanan publik, maka semakin jelas bahwa kebutuhan ilmu pengetahuan kepolisian harus menjadi bagian dari pengembangan profesi seorang polisi yang diharapkan mampu mengidentifikasi dan memahami setiap permasalahan yang dihadapi serta pemecahan yang rasional.

Polisi sipil menghormati hak-hak sipil; masyarakat demokratis membutuhkan polisi sipil yang mampu berperan sebagai pengawai sipil. Nilainilai ini telah dirumuskan dalam Hak Asasi Manusia yang dijamin sebagai hukum positif negara (the guardian of civilian values). Karakter sipil secara luas dikaitkan dengan nilai-nilai peradaban (civilization) dan keadaban (civility).

Pada polisi sipil melekat sikapsikap budaya yang sopan, santun, ramah, tidak melakukan kekerasan, dan mengedepankan persuasi menjadi ciri utamanya. Secara diametral jauh dari karakteristik militer, sejalan dengan definisi yang diangkat dalam perjanjian hukum internasional yang meletakkan kedudukan polisi sebagai kekuatan yang tidak terlibat perang (non-combatant), sementara militer didesain untuk berperang (combatant). Fungsi kepolisian ditujukan untuk menciptakan keamanan dalam negeri, ketertiban dalam 
masyarakat, pelayanan dan bantuan kepada masyarakat, penegakan hukum dan pemolisian masyarakat (community policing). Dan kualitas polisi sipil diukur dari kemampuannya untuk menjauhkan diri dari karakter militer dan mendekatkan diri kepada masyarakat (Mardianto, 2010: 8-15).

Polisi sipil lebih diwakili oleh "pelayanan" (Service) dari pada kekuatan (Force). Banyak hal yang harus menjalani dekonstruksi sebelum sampai kepada pelayanan, termasuk pengubahan mental dan karakteristik anggota kepolisian dijajaran Polrestabes Medan. Visi kepolisian saat ini bukan sekadar sebagai aparat penegak hukum, tapi sebagai polisi yang mampu menjadi profesional, modern dan terpercaya, yang selalu dekat dan bersama-sama masyarakat, penegak hukum yang profesional dan proporsional serta menjunjung tinggi supremasi hukum dan HAM; pemelihara keamanan dan ketertiban masyarakat untuk mewujudkan keamanan dalam negeri dalam suatu kehidupan nasional yang demokratis dan masyarakat yang sejahtera, sehingga pembangunan Polri diarahkan menuju polisi sipil (Civilian Police).

\section{Leadership (Kepemimpinan)}

Kepemimpinan merupakan proses mempengaruhi organisasi dalam mencapai tujuan, dimana perlunya untuk memberikan motivasi perilaku kepada masyarakat untuk mencapai tujuan dan dapat mempengaruhi kelompok dan budaya. Dalam menjalankan tugas dan fungsinya Kapolrestabes Medan memiliki strategi komunikasi pada rencana, strategi, dan keputusannya pada anggota dan komitmen dan tugas pokok yang sudah menjadi tanggungjawabnya seperti melakukan pelayanan kepada masyarakat. Beberapa komitmen yang dipegang sesuai dengan tugas pokok kepolisian adalah seperti menjadikan diri sebagai kepemimpinan yang pelayan, transformasional, keteladanan dan Mengarahkan (Directing).

Dalam mengupayakan pelayanan publik yang sesuai dengan tuntutan dan harapan masyarakat akan keadilan dan responsitivitas yang baik Polrestabes Medan telah menempatkan diri sebagai pelayan masyarakat dengan membuka ruang untuk menerima aspirasi masyarakat dan memberikan solusi pemecahannya seperti adanya aduan dan keluhan dari masyarakat tentang kualitas pelayanan. Kepemimpinan yang 
diterapkan ini merupakan suatu model kepemimpinan yang memprioritaskan pelayanan kepada masyarakat, bawahan/anggota personil dan organisasi kelembagaan.

Praktik kepemimpinan pelayan yang dilakukan Polrestabes Medan ditandai dengan meningkatnya keinginan untuk melayani pihak lain dengan melakukan pendekatan secara menyeluruh pada pekerjaan, komunitas, serta proses pengambilan keputusan yang melibatkan semua pihak. Pemimpin pelayan mengenali kehormatan dan pentingnya nilai setiap individu karena mereka adalah ciptaan Tuhan yang mulia.

$$
\text { Sehingga pemimpin pelayan }
$$

merasa berkewajiban untuk terlibat dalam pembentukan para pengikutnya menjadi manusia yang seutuhnya, yaitu dengan menciptakan lingkungan kerja yang mampu memberi dukungan demi terpenuhinya proses pembentukan tersebut.Salahsatu bentuk kehadiran Polrestabes dalam wujud kepemimpinan dapat dilihat pada gambar.

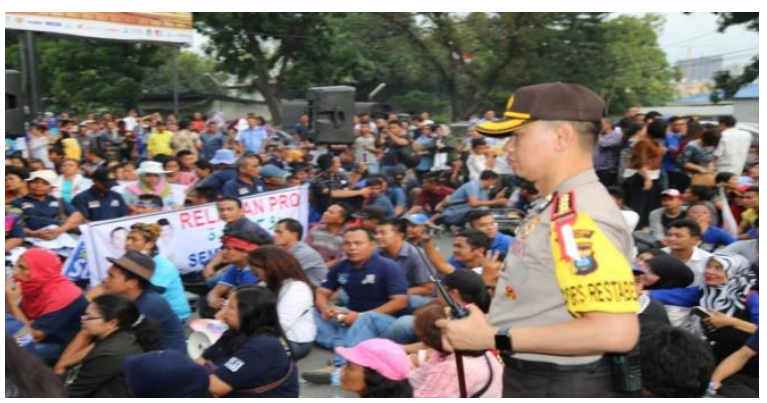

Gambar 1. Kapolrestabes hadir di tengahtengah masyarakat memberikan pengarahan

Dalam hal ini tersebut bentuk arahan tersebut seperti proses pembimbingan, pemberian petunjuk,dan instruksi kepada bawahan/ anggota personil agar mereka bekerja sesuai dengan rencana yang telah ditetapkan. Membuat/ mengusahakan para anggota kepolisiam melakukan apa yang diinginkan dan harus mereka lakukan. Melibatkan kualitas, gaya dan kekuasaan pemimpin serta kegiatan-kegiatan kepemimpinan (motivasi, komunikasi).

Tujuan pengarahan tersebut untuk menjamin kontinuitas perencanaan, membudayakan prosedur standar, menghindarkan kemangkiran yang tak berarti, membina disiplin kerja dan membina motivasi yang terarah. Cara-cara pengarahan yang dilakukan oleh Polrestabes adalah: 
a. Orientasi, dengan cara pengarahan dengan memberikan informasi yang perlu supaya kegiatan dapat dilakukan dengan baik.

b. Perintah, merupakan permintaan dari pimpinan kepada orang yang berada di bawahnya untuk melakukan atau mengulangi suatu kegiatan tertentu pada keadaan tertentu.

c. Delegasi wewenang dengan cara melimpahkan sebagian dari wewenang yang dimilikinya kepada bawahannya.

Kemampuan Polrestabes untuk memotivasi dan mempengaruhi, mengarahkan dan berkomunikasi akan menentukan efektifitas.. Salahsatu bentuk pengarahan yang dilaksanakan dapat dilihat pada gambar berikut ini:

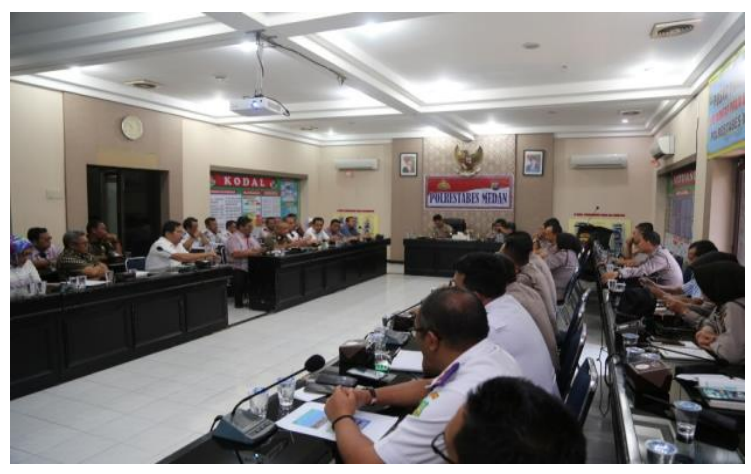

Gambar 2. Kapolrestabes memberikan Arahan kepada semua satuan tentang WBBM

\section{Keteladanan}

Keteladanan merupakan suatu cara atau jalan yang ditempuh oleh seorang pimpinan dengan cara memberikan teladan yang baik kepada bawahannya agar ditiru dan dilaksanakan. Dalam proses mewujudkan wilayah birokrasi bersih dan melayani, Kapolrestabes menggunakan metode dalam menyampaikan arahan dan pembinaan anggota personil/ bawahan salahsatunya metode keteladanan. Tujuan diterapkannya metode keteladanan tersebut adalah untuk meningkatkan efisiensi dan efektifitas visi dan misi organisasi kepolisian serta sebagai pembelajaran sikap di tingkat internal Polrestabes Medan.

Untuk mengembangkan sikap atau perilaku anggota personil, Kapolrestabes tidak hanya memberikan prinsip saja, tetapi figur yang memberikan keteladanan dalam menerapkan prinsip tersebut, sehingga bisa membawa mereka ke arah tujuan yang tegas dan harus menjadi model atau suri teladan masyarakat juga. Dengan adanya model itu dan rela menerima petunjuk maupun teguran bahkan hukuman. 
Hal-hal yang menjadi pertimbangan dalam menggunakan metode keteladanan sebagai metode pembelajaran sikap yaitu tentang apa, mengapa dan bagaimana penerapan metode keteladanan dalam pembelajaran sikap tersebut.

Metode keteladanan dalam kepolisian sebagai suatu metode pembelajaran sikap digunakan untuk merealisasikan tujuan pokok dan fungsi POLRI agar dapat berkembang baik secara fisik maupun mental dan memiliki akhlak yang baik dan benar. Untuk mengembangkan sikap atau perilaku yang baik, pimpinan tidak cukup hanya memberikan prinsip saja, karena yang lebih penting anggota kepolisian.

Alasan menggunakan keteladanan sebagai metode yang dianggap efektif karena pada dasarnya lebih cenderung pada pembentukan sikap dan perilaku, bukan hanya pada teori saja. Dengan kata lain penanaman nilai-nilai sikap itu hendaknya bukan hanya pada ranah kognitif saja, yang berupa pengetahuan moral, melainkan harus berdampak positif terhadap ranah afektif dan psikomotor yang berupa sikap dan perilaku anggota kepolisian dalam melayani kebutuhan dan keinginan masyarakat sehari-harinya.

Adapun bentuk pembelajaran sikap yang telah dilakukan oleh Polrestabes Medan meliputi langkah orientasi, pemberian contoh, dan tindak lanjut. Langkah-langkah tersebut tidak harus selalu berurutan, melainkan berubahubah sesuai dengan kebutuhan. Dengan proses seperti itu, diharapkan apa yang pada awalnya sebagai pengetahuan (kognitif), kini menjadi sikap (afektif), dan kemudian berubah wujud menjelma menjadi perilaku (Psikomotorik) yang dilaksanakan sehari-hari.

Adapun bentuk keteladanan yang diberikan adalah teladan sikap yang mulia, misalnya keteladanan bermurah hati dengan melakukan kunjungan kerumahrumah warga tidak mampu dan memebrikan bantuan, melaksanakan jumat berkah bagi sembako, berlaku jujur dan adil, kasih sayang, penampilan yang sopan, santun dalam bertutur kata, menciptakan hubungan yang harmonis dengan masyarakat, tokoh agama, tokoh masyarakat, tokoh pemuda dan lainnya.

Contoh keteladanan di atas merupakan modal dalam mendukung keberhasilan lembaga kepolisian dalam wewujudkan wilayah birokrasi bersih dan 
melayani. Dengan menjadikan pimpinan sebagai modeling dalam tingkah laku/sikap maka akan tercipta hubungan harmonis dalam internal kepolisian.

Demi berhasilnya pemebelajaran sikap dan tersebarnya ideologi, maka harus ada contoh atau teladan yang baik, menarik perhatian, juga harus ada akhlak utama yang dianut oleh siswa, dan meninggalkan untuk generasi berikutnya yang baik. Berikut ini disajikan gambar kegiatan Kapolrestabes Medan dalam menunjukkan sifat keteladanannya sebagai berikut:

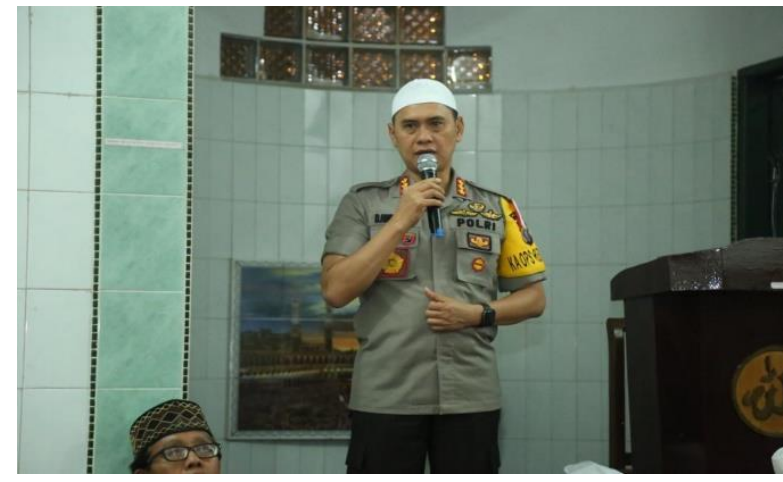

Gambar. 3. Kapolrestabes Memberikan Ceramah Usai Sholat Subuh Keliling

Berdasarkan Permenpan 52 tahun 2014 yang dimaksud dengan predikat WBBM, adalah: "Predikat yang diberikan kepada unit kerja yang memenuhi sebagian besar Manajemen Perubahan, Penataan Laksana, Penataan Sistem SDM, Penguatan Pengawasan dan Penguatan Akuntabilitas
Kinerja dan Peningkatan Kualitas Layanan Publik.

Untuk dapat meningkat menjadi unit kerja berpredikat WBBM, sebuah unit bersatatus WBK harus melakukan peningkatan terhadap kualitas layanan publik. Unit kerja ini dituntut untuk meningkatkan pelayanan publiknya kepada stakeholder dan kemudian melakukan inovasi-inovasi dan terakhir tentunya menjaga agar kualitas layanan tetap terjaga. Dalam hal ini Polrestabes Medan telah meraih predikat Wilayah Bebas Korupsi pada tahun 2018, sehingga untuk jenjang berikutnya unit kerja Polrestabes Medan telah mengajukan usulan sebagai Wilayah Birokrasi Bersih dan Melayani (WBBM).

Untuk mendapat predikat ini unit kerja harus memenuhi komponen yang telah dipersyaratkan seperti komponen inti WBBM yaitu komponen pengungkit terdiri dari 6 komponen (manajemen merubahan, penataan tatalaksana, penataan sistem SDM, penguatan pengawasan , penguatan akuntabilitas, penguatan Kualitas Pelayanan Publik dan komponen hasil terdiri dari 2 komponen ( peningkatan pelayanan publik dan pemerintah yang bersih dan bebas dari KKN. 


\section{DAFTAR PUSTAKA}

Agustina, 2015. Komunikasi Pemasaran Melalui Media Baru Di Serambi Botani, Puslitbang Aplikasi Informatika dan Informasi dan Komunikasi Publik, Badan Litbang SDM, Jurnal Masyarakat Telematika dan Informasi Vol. 6 No. 2 November 2015 Hal.: 129 - 138

https://pengumpul02ilmu.wordpress.com /2012/07/09/saluran-atau-mediakomunikasi-pembangunan/

Karnavian, T. 2017. Democratic Policing: Jakarta : Pensil-324

Keputusan Kepala Kepolisian Negara Republik Indonesia Nomor : Kep / 580 / VI / 2016 tanggal 9 Juni 2016 tentang Petunjuk Pembangunan Zona Integritas menuju Wilayah Bebas dari Korupsi (WBK) dan Birokrasi Bersih dan Melayanai (WBBM) di Lingkungan Polri.

Kumorotomo, Wahyudi. 2015. Etika Administrasi Negara. Jakarta: Raja Grafindo Persada

Mardalis , Ahmad. 2017, Pemanfaatan Media Sosial Untuk Membangun Kepercayaan Merk"Fakultas Ekonomi dan Bisnis Universitas Muhammadiyah Surakarta

Mukarom, Zainal. 2015.Manjemen Pelayanan Publik. Bandung: Pustaka Setia

Muyadi, Dedi. 2015. Studi Kebijakan Publik dan Pelayanan Publik. Bandung: Alfabeta

Nugroho, Riant. 2014. Public Policy: Teori, Manajemen, Dinamika, Analisis,
Konvergensi dan Kimia Kebijakan. Jakarta: Elex Media Komputindo Parsons, Wayne. 2005. Public Policy: Pengantar Teori dan Praktik Kebijakan Publik. Jakarta: Kencana Syafiie, K, Inu. 2003. Sistem Administrasi Negara Republik Indonesia (SANRI). Jakarta: Bumi Aksara

Siagian, P. 2012. Teori Pengembangan Organisasi. Jakarta. Bumi Aksara

Thoha, Miftah,. 2008. Ilmu Administrasi Publik Kontemporer. Jakarta: Kencana

UU 28/1999 tentang Penyelenggara Negara yang Bersih dan Bebas dari Korupsi, Kolusi dan Nepotisme;

UU 31 / 1999 tentang Pemberantasan Tindak Pidana Korupsi;

UU 30 / 2002 tentang Komisi Tindak Pidana Korupsi;

UU 14 / 2008 tentang Keterbukaan Informasi Publik ;

UU 25 /2009 tentang Pelayanan Publik PP 60 / 2008 tentang Sistem Pengendalian Internal Pemerintah;

Perpres 54 / 2010 tentang Pengadaan Barang/Jasa Pemerintah;

Perpres 81 / 2010 tentang Grand Design Reformasi Birokrasi 2010 - 2025;

Perpres 55 / 2012 tentang Strategi

Nasional Pencegahan dan Pemberantasan Korupsi Inpres 2 /2014 Tentang Aksi Pencegahan dan Pemberantasan Korupsi;

Permen PAN dan RB 14 / 2014 tentang Pedoman Evaluasi Pelaksanaan Reformasi Birokrasi www.sbm.itb.ac.id/id//menciptakan- 